\title{
A review of historical trends in the distribution and abundance of elephants Loxodonta africana in Mozambique
}

\author{
C.P. Ntumi, S.M. FerReira and R.J.van A A R D
}

\begin{abstract}
The elephant Loxodonta africana population of Mozambique has declined rapidly over the last 4 decades. Historical census data are incomplete but suggest that the impact of human activity on the elephant population increased after the onset of the colonial era. Demand for ivory explains the population decline from 1700 to 1940, and the killing of elephants as part of settlement policies and tsetse fly control programmes further reduced the populations between 1940 and 1960. Land transformation from 1900 onwards may also have contributed to the historical decline in elephant numbers. Our assessment suggests that landscape approaches should be explored in seeking to conserve elephants in modern Mozambique.
\end{abstract}

Keywords Elephant, fragmentation, historical trend, ivory trade, Loxodonta africana, Mozambique, population

\section{Introduction}

$\mathrm{H}$ istorical accounts (Barreto, 1745; Rodrigues, 1917; Martinho, 1968; Pardal, 1996) suggest that elephants Loxodonta africana were once abundant throughout Mozambique. However, trophy hunting, poaching, civil war, tsetse fly control, agricultural development and pastoral expansion induced a sharp decline in elephant numbers (Smithers \& Tello, 1976; Douglas-Hamilton, 1984; DNFFB, 1991). Consequently, elephants now exist in relatively small populations both beyond and within conservation areas administered by the Direcção Nacional das Áreas de Conservação (DNAC).

The decline of elephant numbers in Mozambique apparently started with the demand for ivory (Dias, 1971) and continued when elephants and other suspected vectors of tsetse-borne trypanosomiasis were eliminated from several regions as part of a programme to control tsetse flies (Dias \& Rosinha, 1971; Smithers \& Tello, 1976). Elephants were declared a pest in 1936 (Frade, 1950) and later cropped to feed the military (Frade, 1950; Dias, 1973). The establishment of

C.P. NTUmi*, S.M. Ferreira and R.J. van Aarde (Corresponding author) Conservation Ecology Research Unit, Department of Zoology and Entomology, University of Pretoria, Hatfield 0028, South Africa. E-mail rjvaarde@ zoology.up.ac.za

*Also at: Department of Biological Sciences, University of Eduardo Mondlane, Maputo, Mozambique.

Received 24 October 2007. Revision requested 11 January 2008.

Accepted 20 May 2008. plantations and agricultural development reduced and fragmented habitats and this may have further reduced elephant numbers (Manghezi, 2003). Poaching continues, as does legal consumptive use through small-scale trophy hunting of elephants (Milliken, 2002; SRN, 2006).

These observations suggest that human activities reduced elephant numbers in Mozambique. Little information, however, is available on elephant numbers, distribution or demography. Few time series of population estimates exist and most estimates are guesses reported in official government reports and NGO documents. Here, therefore, we compile all available historical data to review the trends in elephant numbers across Mozambique. To establish if trends in numbers could be explained by socioeconomic changes we collated historical information on the numbers of elephants and people living in Mozambique, data on the ivory trade and tsetse fly control campaigns, and information on the export of some agricultural products and recent land-use changes.

\section{Study area}

Mozambique covers c. $800,000 \mathrm{~km}^{2}$ along the east coast of southern Africa (Fig. 1a). The human population of 20.5 million people is increasing at c. 2.2\% per year (INE, 2007). Annual rainfall varies from 1,00o $\mathrm{mm}$ in the northern and southern provinces to $1,200 \mathrm{~mm}$ in the central provinces (Instituto Nacional de Meteorologia, 2007). The country consists of a series of isolated harbours and settlements, each surrounded by a belt of rural estates that traded with the independent hinterland when it became an overseas province of Portugal in 1890 (Liesegang, 1983). The present borders were drawn in 1891 (Hatton et al., 2001). Ivory and slaves were widely traded in the 16-19th centuries (Liesegang, 1983).

Dry and moist miombo woodlands are common in the northern and central provinces, and mopane woodlands dominate the Limpopo-Save region and the mid Zambezi valley (Hatton et al., 2001). The last two wars (1964-1974 and 1978-1992) devastated large mammal populations in areas of high biological and scenic value (Hatton et al., 2001). Currently c. 16,00o elephants (Blanc et al., 2007) live in five National Parks, five National Reserves, 13 Controlled Hunting Areas, one Forest Reserve, and in areas beyond protected areas (DNAC, 2006; Fig. 1b). The elephant population of Niassa National Reserve is the largest, with $>10,000$ elephants in 2004 (Craig \& Gibson, 2004). 
(a)

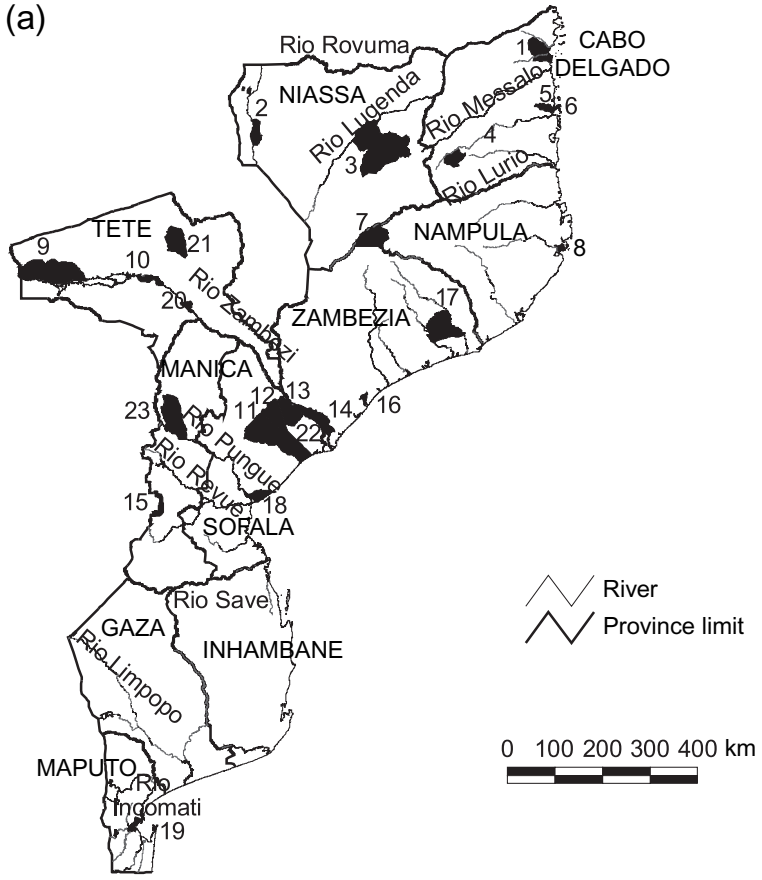

(c)

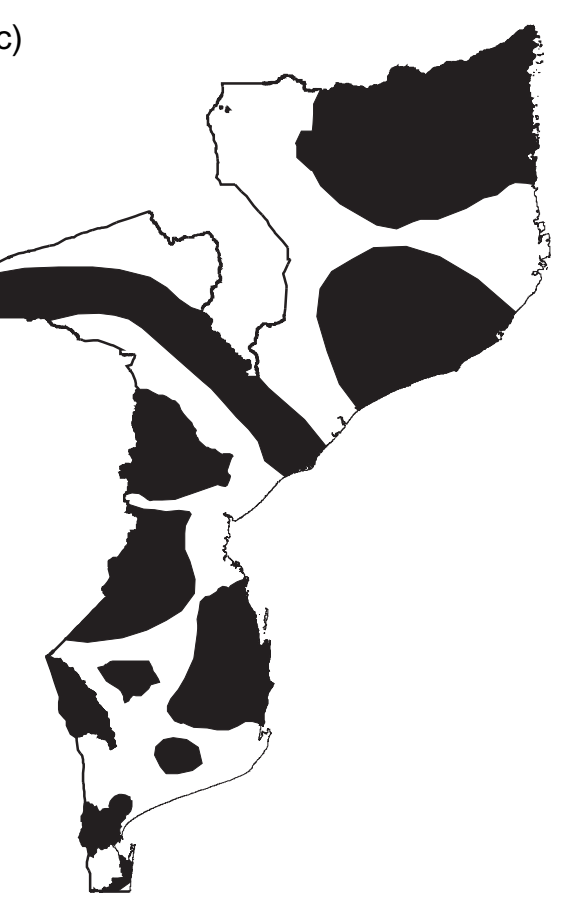

(b)

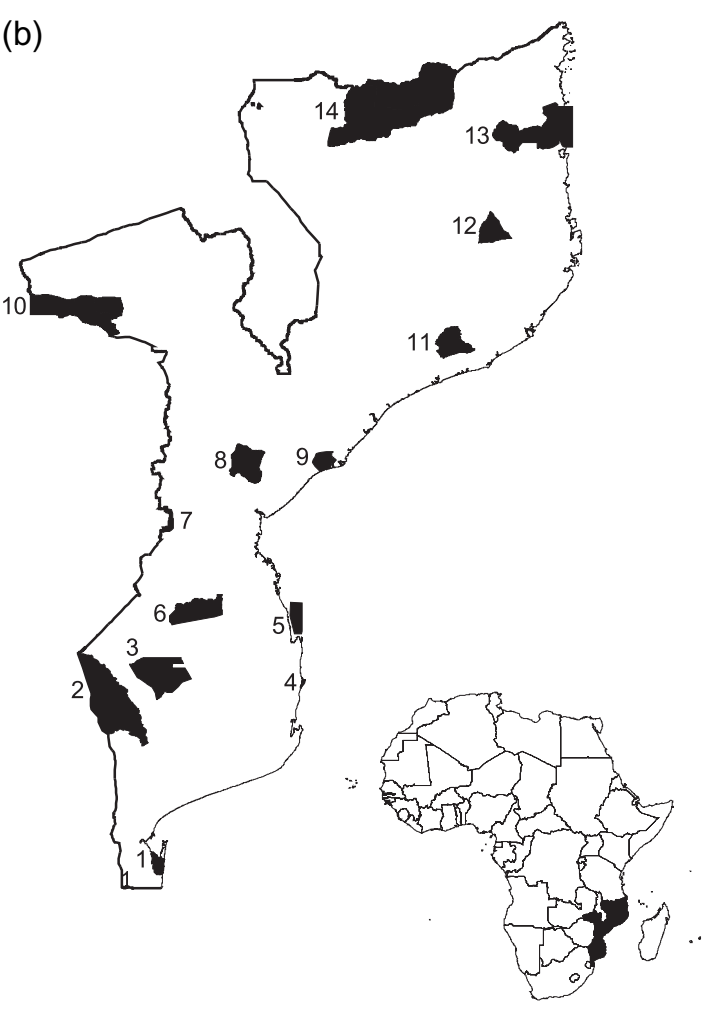

(d)

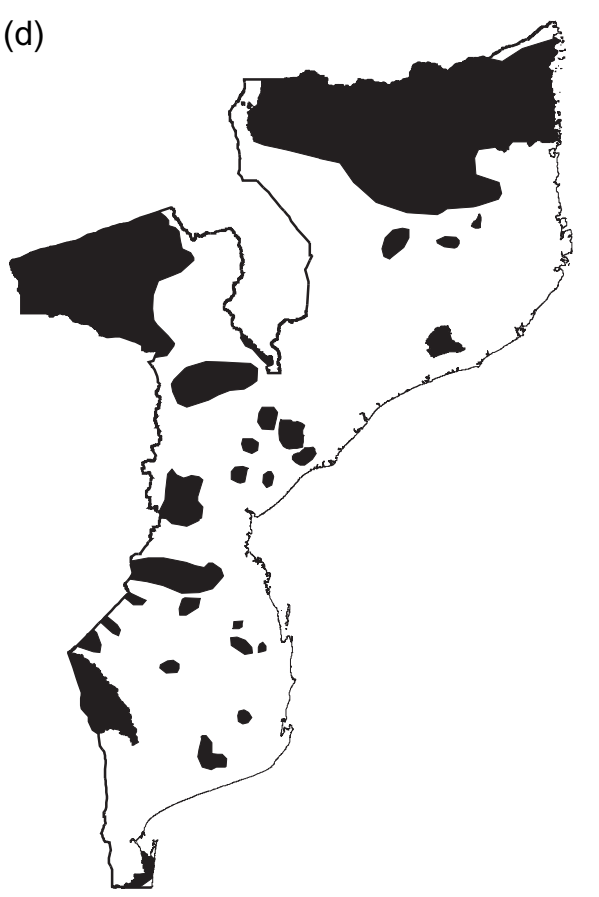

Fig. 1 (a) Mozambique, showing the most relevant historical locations mentioned in the text. 1, Mocimboa da Praia; 2, Metangula; 3 , Marrupa; 4, Balama; 5, Quissanga; 6, Quirimbas; 7, Mutuali; 8, Ilha de Moçambique; 9, Zumbo; 10, Songo; 11, Inhaminga; 12, Inhamitanga; 13, Shupanga; 14, Luabo; 15, Chimanimani; 16, Quelimane; 17, Gilé National Reserve; 18, Beira; 19, Maputo; 20, Tete; 21, Cazula; 22, Cheringoma; 23, Vila Gouveia. (b) National Parks, Reserves and Community Game Farms that harbour elephants in Mozambique (1, 2, 3, 6, 7, 8, 9, 10,11, 12, 13 and 14), and others (4 and 5) protecting coastal and marine diversity (modified from DNAC official map). 1, Maputo National Reserve; 2, Limpopo National Park; 3, Banhine National Park; 4, Zinave National Park; 5, Pomene National Reserve; 6, Bazaruto National Park; 7, Chimanimani National Reserve; 8, Gorongosa National Park; 9, Marromeu National Reserve; 10, Tchuma Tchato Community Game Farm; 11, Gilé National Reserve; 12, Mecubúri Forest Reserve; 13, Quirimbas National Park; 14, Niassa National Reserve. (c) Former (1940-1960) elephant range in Mozambique (BEE, 1925-1970; RP, 1952). (d) Reduced and fragmented present elephant range (DNFFB, 1991, 1999; Blanc et al., 2003). Inset shows location of Mozambique in Africa. 


\section{Methods}

Our primary sources of information on human densities, land-use change and the quantity of ivory exported since the 1700s include the National Archive of Mozambique's History, the National Ultramarine Archive of Portugal, reports held by the former Direcção Nacional de Florestas e Fauna Bravia (DNFFB), reports by NGOs operating in Mozambique, and the libraries of the Universities of Eduardo Mondlane, Pretoria, South Africa, and Zimbabwe. For information on elephant distribution and relative abundance we relied on descriptions of naturalist travellers, missionaries and professional hunters since the 1500 s. Aerial reconnaissance and informed guesses formed the basis of the few elephant population estimates after 1900.

We addressed the historic trends in elephant numbers for the pre-colonial era (before 1500), the colonial era (1500-1975) and the post-colonial era (after 1975). For the pre-colonial era we relied on an interpretation of archaeological information. For the colonial era we found only three elephant censuses and derived likely trends in elephant numbers from records of exported ivory and on the number of elephants killed as part of tsetse fly control programmes. For the post-colonial era we collated data from structured surveys $(n=22)$ and guesses $(n=32)$.

We fitted exponential models (Caughley, 1977) to both human (extracted from national censuses) and elephant numbers to identify trends and rates of change since 1900 . We used linear regression (Sokal \& Rohlf, 1995) to determine if a relationship existed between people and elephant numbers. We examined trends in the ivory trade and agricultural products with available data from the 1700 s to 1980 , and changes in land-use patterns and sizes of areas allocated to agriculture and forest exploitation over 1925-1975.

\section{Results}

\section{The pre-colonial era}

Our understanding of elephant distribution during this era is based on deductive speculation. Low human densities and relatively inefficient hunting may have allowed elephants to be relatively common and widely distributed over Mozambique (Klein, 1987; Owen-Smith, 1999). Paintings, engravings and excavated artefacts dating back to the Late Stone Age (Deacon, 1984) from archaeological sites in Mozambique (Silva, 1980; Adamowicz, 1987; Sinclair, 1987; Duarte, 1989) as well as the presence of pits, weighted spears and axes that were used to hunt (Duarte, 1989) and rock sketches of elephants in shelters (Dutton \& Dutton, 1973; Adamowicz, 1987; Sinclair, 1991) suggest that elephants may have ranged throughout Mozambique (Lewis, 1987; Woodhouse, 1996; Eastwood \& Blundell, 1999; Whyte et al., 2003).
As elsewhere across southern Africa (Maggs, 1984) the transition from hunting and gathering to food production in Mozambique occurred during the Holocene (Adamowicz, 1987; Stock \& Pfeiffer, 2001). By AD 500 people produced crops and kept domestic animals (Maggs, 1984) while living in small, scattered villages (Lee \& Graham, 2006). The expansion of human populations and activities during the Iron Age (Harpending et al., 1993; Sherry et al., 1994) conceivably changed the environment, and increased hunting may have had a modest impact on elephants (Owen-Smith, 1999).

\section{The colonial era}

Elephant distribution and abundance in Mozambique changed when merchants arrived and started to supply guns (Gann, 1965). Market demand fuelled by the needs of the Islamic empire (Alpers, 1975) brought specialist and extensive elephant hunting expeditions into Mozambique during 1800-1875 (Hedges, 1978), and the ivory trade flourished at this time (Fig. 2) supporting the notion that elephants were then probably numerous and widespread (Sanderson, 1962; Shepperson, 1965; Bere, 1966; Selous, 1984; Adams \& McShane, 1992). At this time c. 340,000 people were taken from Mozambique as slaves (Capela \& Medeiros, 1987), most of them from north of the Zambezi River (Capela \& Medeiros, 1987) where elephants apparently flourished (Shepperson, 1965; Maugham, 1914).

With the decline of the slave trade from 1845 (Capela \& Medeiros, 1987) human numbers started to increase, and agricultural activities expanded and may have reduced elephant populations. From 1880 to 1920 copra and sugar exports increased (Fig. 2) and contributed greatly to revenue. In addition, from 1800 onwards, transport services to neighbouring territories and migrant labour gradually became more important economic activities (Liesegang, 1983).

Land-use activities expanded from 1900 (Fig. 3d) and landscape fragmentation and/or loss of habitat may have compressed elephants into refuge areas (Lyell, 1910, 1924; Maugham, 1914; Rodrigues, 1917; Dalquest, 1965) as noted elsewhere in Africa (Lee \& Graham, 2006). These refuge areas were mostly in the hinterland but a few were in the country's coastal zones (Chamberlain, 1923). In some of these refuge areas, such as Niassa province, the Luabo district extending south of the Zambezi delta to the Shupanga forest and Cheringoma, and from Maputo to the Save River, elephant numbers increased from 1930 (RP, 1952) and their distribution expanded again but remained fragmented (Fig. 1c).

Official responses to apparent elephant range expansion and threats to crop production included the declaration of elephants as a pest species in 1936 (Frade, 1950). Further legalization of elephant killing through the replacement of the Conservation Act of 1955 with the Professional Meat 

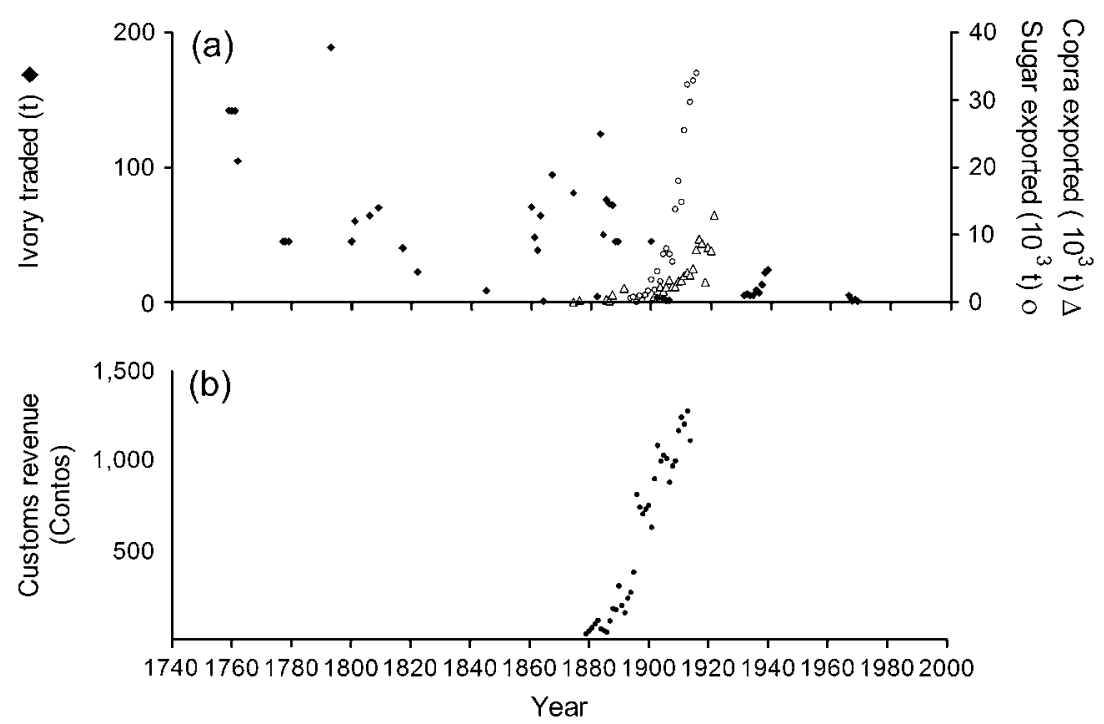

FIG. 2 (a) The amount of ivory traded in Mozambique declined from the 1700s to the late 1900s (data collated from Jordão, 1870; BEE, 1925-1970; AEC, 1926-1973; Hedges, 1978; Liesegang, 1983; Sheriff, 1983; Barbier et al., 1992; Spinage, 1994), whilst exports of copra and sugar increased (exports of copra are for Quelimane port; exports of sugar are records of export territories administrated by the State and by the Companhia de Moçambique in Manica and Sofala; data collated from BEE, 1925-1970; AEC, 1926-1973; Liesegang, 1983). (b) Revenue, expressed in contos of reals. Reals (reis) were the colonial currency. The so called weak reals (reis fracos) were introduced in the 18th century. By devaluation weak reals changed to strong reals. A conto corresponds to 1,000,000 reis. Revenue data are the records of the Lourenço Marques port (now Maputo; data collated from BEE, 1925-1970; AEC, 1926-1973; Liesegang, 1983).

and Ivory Hunting Act in 1960 (Dias, 1973; Smithers \& Tello, 1976) formalized actions to reduce elephant numbers in areas beyond the protected areas established in the 1960s (Martinho, 1968). The establishment of these areas conceivably relieved elephants from formal and informal persecution and may have resulted in an increase in elephant numbers from the 1960s to 1970s (Dias, 1973).

From the 1960s onwards, elephants from Mozambique also dispersed to neighbouring countries. For example, elephants from Mozambique populated the Kruger National Park (Whyte et al., 2003) and elephants in the Chimanimani, Zumbo and Rovuma-Lugenda regions (Fig. 1a) migrated into Zimbabwe, Zambia and Tanzania (Dutton, 1975; Davies, 1999; Hofer et al., 2004). The liberation war of 1964-1974 further reduced elephant numbers when both Frente de Libertação de Moçambique and colonial troops killed elephants to feed soldiers and used ivory to fund their campaigns (Dias \& Rosinha, 1971).
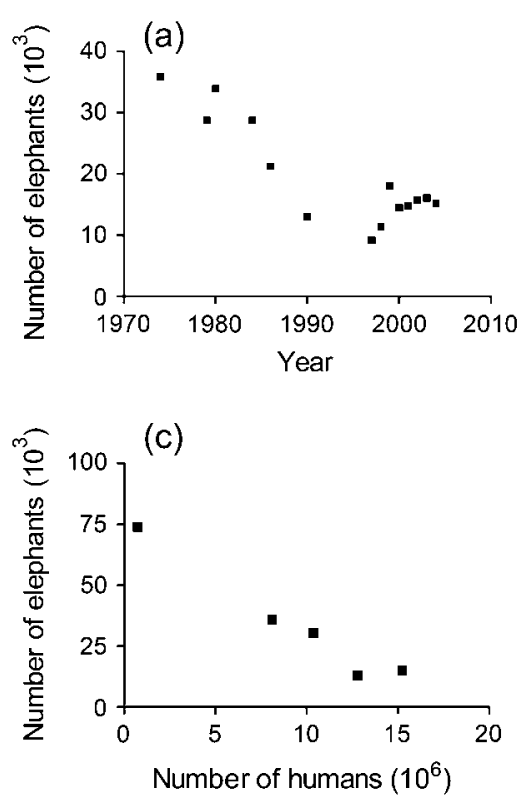
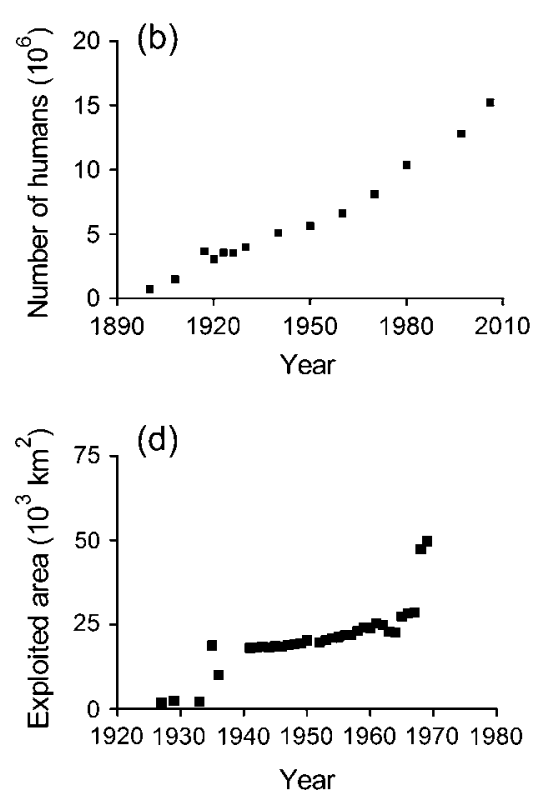

Fig. 3 Estimates of the (a) elephant (1974-2004) and (b) human population (1900-2009) in Mozambique (elephant data: DNFFB, 1999; Cumming \& Jones, 2005; Table 1; human data: BEE, 19251970; AEC, 1926-1973; INE, 1980, 1999). (c) The elephant population declined as human numbers increased. (d) Exploited areas (agriculture and forestry combined) in Mozambique increased from the 1920s to the 1970s (AEC, 1926-1973). 
TABLE 1 Estimates (with 95\% confidence interval) of elephant numbers in conservation areas in Mozambique by survey area and year, with survey method and data source.

\begin{tabular}{|c|c|c|c|}
\hline Survey area $\left(\mathrm{km}^{2}\right) /$ year & Survey method & Estimate $(95 \% \mathrm{CI})$ & Source \\
\hline \multicolumn{4}{|c|}{ Niassa National Reserve $(42,349)$} \\
\hline 1980 & Guess & 10,000 & WWF/IUCN (1980) \\
\hline 1997 & Aerial survey & $6,500(6,000-7,000)$ & Leo-Smith et al. (1997) \\
\hline 1998 & Aerial survey & $8,707(6,770-10,644)$ & Gibson (1998) \\
\hline 2000 & Aerial survey & $11,828(9,688-13,968)$ & Gibson (2000) \\
\hline 2002 & Aerial survey & $13,061(10,579-15,543)$ & Craig \& Gibson (2002) \\
\hline 2004 & Aerial survey & $12,477(10,355-14,599)$ & Craig \& Gibson (2004) \\
\hline \multicolumn{4}{|c|}{ Lugenda-Rovuma Reserve $(15,000)$} \\
\hline 1981 & Aerial survey & 823 & Taylor (1981) \\
\hline 1998 & Guess & 300 & Barnes et al. (1999) \\
\hline \multicolumn{4}{|c|}{ Quirimbas National Park $(7,845)$} \\
\hline 2002 & Guess & 90 & Blanc et al. (2003) \\
\hline 2004 & Guess & 1,000 & Cumming \& Jones (2005) \\
\hline 2006 & Ground count & 1,492 & Araman \& Mahommed (2006) \\
\hline \multicolumn{4}{|c|}{ Mecuburi Forest Reserve (195) } \\
\hline 2000 & Guess & 5 & Blanc et al. (2003) \\
\hline \multicolumn{4}{|c|}{ Gilé National Reserve $(2,100)$} \\
\hline 1973 & Aerial survey & 39 & Dutton \& Dutton (1973) \\
\hline 2002 & Guess & $15-18$ & Martins \& Ntumi (2002) \\
\hline \multicolumn{4}{|c|}{ Tchuma Chato Community Area $(3,815)$} \\
\hline 1980 & Aerial survey & 1,274 & Mackie \& Chafota (1995) \\
\hline 1995 & Aerial survey & 137 & Mackie \& Chafota (1995) \\
\hline 1999 & Aerial survey & $400(154-646)$ & Davies (1999) \\
\hline 2000 & Aerial survey & 1,217 & Mackie (2001) \\
\hline 2004 & Aerial survey & $1,264(983-1,545)$ & Mackie (2004) \\
\hline \multicolumn{4}{|c|}{ Marromeu National Reserve $(1,500)$} \\
\hline 1968 & Aerial survey & 257 & Dutton (1994) \\
\hline 1977 & Guess & 331 & Hatton et al. (2001) \\
\hline 1978 & Guess & 361 & Hatton et al. (2001) \\
\hline 1979 & Guess & 373 & Dutton (1994) \\
\hline 1990 & Guess & 326 & Dutton (1994) \\
\hline 1994 & Aerial survey & 0 & Dutton (1994) \\
\hline 1998 & Guess & 589 & Hatton et al. (2001) \\
\hline 2000 & Guess & 219 & Hatton et al. (2001) \\
\hline 2001 & Guess & 421 & Hatton et al. (2001) \\
\hline 2005 & Aerial survey & 388 & AWF (2005) \\
\hline \multicolumn{4}{|c|}{ Gorongosa National Park $(5,300)$} \\
\hline 1968 & Aerial survey & 2,200 & Dutton (1994) \\
\hline 1970 & Guess & 1,900 & Hatton et al. (2001) \\
\hline 1972 & Guess & 2,542 & Tello (1986) \\
\hline 1979 & Guess & 3,000 & Hatton et al. (2001) \\
\hline 1980 & Guess & $3,500-5,000$ & WWF/IUCN (1980) \\
\hline 1993 & Guess & 4 & Dutton (1994) \\
\hline 1994 & Aerial survey & 108 & Cumming et al. (1994) \\
\hline 2000 & Guess & 163 & Hatton et al. (2001) \\
\hline 2001 & Guess & 111 & Hatton et al. (2001) \\
\hline 2005 & Aerial survey & 300 & Cumming \& Jones (2005) \\
\hline \multicolumn{4}{|c|}{ Chimanimani-Moribane Transfrontier Conservation Area (735) } \\
\hline 1973 & Guess & 12 & Dutton \& Dutton (1975) \\
\hline 2003 & Guess & 22 & Sitoe et al. (2003) \\
\hline \multicolumn{4}{|c|}{ Zinave National Park $(3,800)$} \\
\hline 1965 & Guess & 1,500 & Dalquest (1965) \\
\hline 2002 & Guess & 22 & Blanc et al. (2003) \\
\hline 2007 & Aerial survey & 0 & Stalmans (2007) \\
\hline
\end{tabular}


TABle 1 (Continued)

\begin{tabular}{|c|c|c|c|}
\hline Survey area $\left(\mathrm{km}^{2}\right) /$ year & Survey method & Estimate $(95 \% \mathrm{CI})$ & Source \\
\hline \multicolumn{4}{|c|}{ Banhine National Park $(7,000)$} \\
\hline 1974 & Guess & $750-1,000$ & Tello (1986) \\
\hline 1986 & Guess & 500 & Tello (1986) \\
\hline 2002 & Guess & 8 & Blanc et al. (2003) \\
\hline 2004 & Aerial survey & 0 & Stalmans (2004) \\
\hline 2007 & Aerial survey & 0 & Stalmans (2007) \\
\hline \multicolumn{4}{|c|}{ Limpopo National Park $(10,000)$} \\
\hline 1974 & Guess & $15,000-20,000$ & Blanc et al. (2003) \\
\hline 2002 & Guess & 150 & Blanc et al. (2003) \\
\hline 2006 & Aerial survey & 630 & Blanc et al. (2007) \\
\hline \multicolumn{4}{|c|}{ Maputo National Reserve (800) } \\
\hline 1911 & Guess & $300-600$ & Barrett (1911) \\
\hline 1970 & Guess & 350 & Tello (1973) \\
\hline 1972 & Guess & 269 & Tinley \& Dutton (1973) \\
\hline 1974 & Guess & 350 & Tello (1986) \\
\hline 1976 & Guess & 300 & Tinley et al. (1976) \\
\hline 1976 & Guess & 210 & Burlinson \& Carter (1976) \\
\hline 1979 & Guess & 80 & Klingelhoeffer (1987) \\
\hline 1986 & Guess & $80-130$ & Tello (1986) \\
\hline 1995 & Guess & 137 & Ostrosky \& Matthews (1995) \\
\hline 1995 & Guess & 150 & Ostrosky \& Matthews (1995) \\
\hline 1996 & Guess & $100-300$ & Correia et al. (1996) \\
\hline 1998 & Guess & 180 & de Boer et al. (2000) \\
\hline 1999 & Guess & 200 & Carnie (1999) \\
\hline 1999 & Aerial survey & 205 & Ntumi (2002) \\
\hline 2006 & Dung count & $311(198-490)$ & $\begin{array}{l}\text { P.I. Olivier, S.M. Ferreira \& } \\
\text { R.J. van Aarde (unpubl. data) }\end{array}$ \\
\hline
\end{tabular}

The post-colonial era

At independence in 1975 many families returned to their villages and started growing crops (Collins, 1978; Lorgen, 1999). This expansion of cultivation reduced elephant ranges further (Smithers \& Tello, 1976; Tello, 1977). Game laws became less restrictive (Taylor, 1981) and probably increased the illegal ivory trade (Milliken, 2002). At that time financial support for elephant conservation in Mozambique was limited (WWF/IUCN, 1980).

The civil war of 1980-1992 may have harmed wildlife (DNFFB, 1991) and further reduced elephant numbers (Dutton, 1992; Hatton et al., 2001). Population estimates were 50,000-65,000 in 1974 (DNFFB, 1991), 54,800 in 1981, 17,000 in 1989 (Barbier et al., 1992) and 13,000 by 1990 (Cumming et al., 1994). From 1975 to 1983 populations in the central and southern regions declined by 65 and $76 \%$, respectively (Douglas-Hamilton, 1984). Rural people populated areas formerly used by elephants. This resulted in the current situation, with a once continuous elephant population fragmented into small populations that mostly live in relatively small conservation areas across a landscape that is dominated by human activities (Fig. 1d).

\section{Recent trends}

Several of the elephant population estimates are guesses (Table 1). Few surveys used standard methods and, when they did, the effort and areas covered varied. All survey areas, except the Maputo National Reserve, were poorly delineated or defined. Most of the populations for which estimates are available are small and isolated (Table 1 ). The current total estimate is 16,000 elephants (Blanc et al., 2007). The best available data suggest that the number of elephants in Mozambique declined exponentially at a mean rate of $3.3 \pm$ SE $0.7 \%\left(F_{1,12}=22.18, \mathrm{P}<0.01\right)$ per annum since 1974. However, estimates post-2000 have not varied significantly $\left(F_{1,3}=2.01, \mathrm{P}=0.25\right.$; Fig. $\left.3 \mathrm{a}\right)$.

Human population censuses suggest a mean increase of $2.3 \pm$ SE $0.3 \%\left(F_{1,12}=76.42, \mathrm{P}<0.01\right)$ per annum since 1900 (Fig. 3b). Data on the links between trends in human and elephant populations are sparse yet elephant numbers declined as the human population increased $\left(F_{1,3}=66.64, \mathrm{P}<\right.$ 0.01; Fig. 3c). By 1938 farmers had deforested many areas where elephants were once common (BEE, 1925-1970). Such disturbances are continuing (Fig. 3d) and few elephants live in parts of provinces such as Nampula and Zambezia 
that are densely populated and extensively modified (Wild \& Barbosa, 1967; Sinclair, 1987; Saket, 1994; DNFFB, 1999). In less densely populated provinces, such as Niassa, Cabo Delgado and Tete, elephants and other wildlife persist widely, especially close to protected areas such as the Niassa National Reserve, the Quirimbas National Park and the Zumbo region. At present, several small populations of elephants occur throughout the southern provinces, such as those in Maputo (Maputo National Reserve, the Futi River and Magude region), Gaza (Limpopo National Park) and Inhambane (along the Save River; Hatton et al., 2001).

\section{Discussion}

The decline in elephant numbers in Mozambique is primarily due to the impact of direct (ivory trade and tsetse control programmes) or indirect human activity (habitat fragmentation and associated factors). People have sought ivory since the early Iron Age ( $\mathrm{AD}$ 815) and European markets have influenced the ivory trade since the 1400 s (Spinage, 1994). Portuguese, Arab and native traders exported 69 tons from Beira (south of Sofala) in 1512-1515 (Spinage, 1994) to India. Dutton (1975) estimated that the ivory taken per year represented c. 1,00o elephants from the region between the Manica and Maputo provinces during the 1500s. By the mid 18th century extensive hunting had expanded onto the interior, with 150-180 tons of ivory taken per year (Sheriff, 1983; Spinage, 1994). These anecdotal descriptions suggest that elephant numbers were high in the 17-19th centuries.

Due to price disagreements the ivory trade apparently collapsed in 1780-1790 (Spinage, 1994) and ivory exports oscillated but declined after 1800 (Liesegang, 1983; Barbier et al., 1992; Spinage, 1994). Much of this variability in exports may have been associated with changes in Mozambique's economy. The ivory and slavery trades that dominated in 1770-1870 (da Silva, 1969) were replaced by other export products (primarily sugar and copra) and ivory accounted for only $32 \%$ of exports by 1874 (Liesegang, 1983).

At least half of Mozambique (c. $400,000 \mathrm{~km}^{2}$ ) was infected by tsetse flies (Glossina spp.) in the 1940s. As part of efforts to eradicate tsetse flies $>3,000$ elephants were killed in 1947-1969 at Mutuáli (Nampula), Govuro (Imhambane), Changara (Tete), Massangena (Gaza) and Muda (Sofala; Blair, 1939; Dias \& Rosinha, 1971). This followed an earlier campaign in the Rio Maputo valley and Likwati forest (Manghezi, 2003) that eliminated most of the elephants west of the Rio Maputo. These campaigns continued until the early 1970s (Dias \& Rosinha, 1971).

Areas cleared of tsetse flies were soon occupied by people and land clearing for agriculture may have prevented coexistence with elephants. Areas earlier cleared of tsetse flies, from Rovuma River south towards Zumbo, Cazula (Macanga District), Marrupa, Balama and Mocimboa da Praia, have now been recolonized by elephants (MINAG, 2006).

More than $80 \%$ of people in Mozambique live in rural areas and depend on natural resources (Del Gatto, 2003). Charcoal production and the collection of wood for fuel are degrading woodlands (Del Gatto, 2003). Although $78 \%$ of the country was covered by natural forests in 1980-1990 (MICOA, 1997) the national deforestation rate in 1972-1990 was c. $4.2 \%$ (MICOA, 1997). In 1990-2000 closed woodlands decreased by c. $13 \%$ (Pereira, 2001). Consequently, habitat available for elephants may be declining and conservation areas are becoming habitat islands in human-dominated landscapes.

Elephants that live in these landscapes may not often come into conflict with people but, at the fine scale, habitat fragmentation may disrupt foraging and breeding and thus lower the population growth rate (Barbault \& Sastrapradja, 1995). This may in part explain the historical decline in elephant numbers from 1900 onwards and the links between trends in human and elephant populations, as well as the relationship between exploited areas and the number of elephants.

Elephant conservation in Mozambique faces a range of challenges associated with the relatively fast human population growth rate. These challenges include the genetic constraints that may arise in small and isolated populations, and that continuing elephant dispersal into formerly occupied areas may result in human-elephant conflict. Our review suggests that the once continuous elephant population of Mozambique is increasingly being fragmented into relatively small areas. However, many of these areas adjoin larger areas and larger elephant populations in neighbouring countries (South Africa, Zambia, Zimbabwe and Tanzania).

The population in the Niassa National Reserve in northern Mozambique is relatively large and seems to be part of a widely distributed regional population. The recently founded population in the Limpopo National Park that adjoins the population of the Kruger National Park in South Africa illustrates that populations in Mozambique may be founded and maintained through dispersal movements from neighbouring populations. Similarly, the elephant population in the Maputo National Reserve could be reconnected through the Futi Corridor to those living in the Tembe Elephant Park, which is presently fenced (Morley \& van Aarde, 2007). The integrity of elephant populations in Mozambique may be best preserved when they are provided the opportunity to be part of larger regional populations. Future conservation of elephants in Mozambique may thus depend on management as several regional populations (van Aarde \& Jackson, 2007) in a system of transfrontier conservation areas (Hanks, 2001).

More than $60 \%$ of Mozambicans are poor and government poverty alleviation strategies (RM, 2006) may conflict 
with elephant conservation ideologies that call for the development of dispersal linkages across human-dominated landscapes. There is a need for solutions that integrate the needs of both people and elephants (Lee \& Graham, 2006). This may well be possible in the large stretches of land where few people live. Increasing urbanization (Maximiano et al., 2005) and recent changes in human demography and distribution, driven by HIV and associated diseases, and migrations for coastal tourism developments, may provide further options to expand elephant range without confronting people.

Conceptual developments that change the focus of conservation from protected areas to a conservation matrix that comprises a range of land-use options across national and international boundaries (van Aarde \& Jackson, 2007) could accommodate the needs of both people and elephants. Although land-use options across international boundaries have been considered in the transfrontier conservation initiatives framework (Hanks, 2001), at a national scale a conservation matrix that accommodates the needs of both people and elephants still requires a systematic assessment and evaluation as well as strategic planning and policy changes.

The National Strategy for Elephant Management in Mozambique (DNFFB, 1999) mostly focuses on the apparent increase of elephant numbers and how it may affect other species and humans. Our assessment indicates that this approach, which assumes that elephants require an economic value for local communities to achieve effective elephant conservation (Bell, 1987; Keats, 1991; Hanks, 2001) and highlights human-elephant conflict dilemmas (Hoare, 2001), is not the most appropriate.

Our recent novel solution to elephant management (van Aarde et al., 2006; van Aarde \& Jackson, 2007) caters for the situation in Mozambique. The mosaic of intact and disturbed landscapes, occupied at varying densities by people and elephants, provides an opportunity to use a metapopulation metaphor on which to base elephant management strategies. Prime elephant habitat can serve as sources to sustain sinks. Sinks may be areas where people live but that are also used by elephants. However, elephant management that relies on dynamic spatial interactions, such as dispersal between source and sink populations across human dominated landscapes, needs information on how elephants and people utilize landscapes and on changes in elephant and human numbers. Such management should focus on inducing local elephant population fluctuations while maintaining regional stability in their numbers and minimizing human-elephant conflict. This may mitigate conflict without placing the elephant population at risk and provide further opportunity for the integration of elephant conservation into a regional economic framework.

Conservation and development authorities in Mozambique may have to maintain landscapes occupied by many elephants and few people as prime conservation areas, e.g. the Niassa-Cabo Delgado region, upper Tete region (Magoe and Zumbo) and Greater Limpopo region. They should also recognize that isolated areas with few elephants, such as Gorongosa-Marromeu Complex, Gilé and Mecuburi, can only persist as conservation areas if linked to larger areas where other elephant populations thrive. This may best be achieved by reinstating spatial and temporal processes in a matrix of landscape uses and by establishing formal transfrontier conservation area agreements in areas with many elephants and much space.

Such ongoing transfrontier conservation area projects include those between Mozambique and Tanzania (the Niassa-Selous initiative and the Rovuma Transfrontier Conservation Area), as well as between Mozambique, South Africa and Zimbabwe (the Great Limpopo Transfrontier Conservation Area) and Mozambique, South Africa and Swaziland (the Lubombo Transfrontier Conservation Area). This approach could also best be explored at a national scale in northern Mozambique to involve the Niassa region, the Quirimbas National Park and the planned Rovuma National Reserve.

Sporadic elephant movements are reported between Mecuburi Forest Reserve and Gilé National Reserve, as well as between Zinave National Park and Banhine National Park. In the south of Mozambique elephant conservation may involve the recolonization of areas across the Magude and Moamba districts. In these cases and at the district level, present community based-conservation initiatives would be best explored because they incorporate the interests of people.

The number of elephants in Mozambique has declined since 1970. People's direct and indirect activities fragmented a once continuous elephant population into a few large and several small populations. The remnant populations could recover through the application of our proposed landscape approach, which allows elephants to disperse and populate landscapes that link subpopulations into a functional metapopulation.

\section{Acknowledgements}

The manuscript benefited from the suggestions made by Gerhard Liesegang, Alessandro Fusari, Robert Guldemond and two anonymous reviewers. Our present research in Mozambique is financed by WWF, the MOZAL Community Development Trust, the Peace Parks Foundation and the International Fund for Animal Welfare. This work is part of the PhD of Cornelio Ntumi, funded by WWF and a special grant from Billiton. We are grateful for data searching at the National Ultramarine Archives in Lisbon by Jen Shaffer from the University of Georgia, USA, and the information provided by the staff of Mozambique's History Archive, and maps generated by Ana Massinga. 


\section{References}

Adamowicz, L. (1987) Contribuição para o conhecimento da Arqueologia entre os rios Lúrio e Ligonha, Província de Nampula. Trabalhos de Antropologia, 3, 47-144.

Adams, J.F. \& McShane, T.O. (1992) The Myth of Wild Africa. W.W. Norton, New York, USA.

AEC (Anuário Estatístico da Colónia de Moçambique) (1926-1973) Estatísticas económicas. Imprensa Nacional de Moçambique, Lourenço Marques, Mozambique.

Alpers, E. (1975) Ivory and Slaves: Changing Pattern of International Trade in East Central Africa to the Later Nineteenth Century. University of California Press, Berkeley and Los Angeles, USA.

Araman, A. \& Mahommed, J.D. (2006) Relatório da contagem terrestre de grandes mamíferos no Parque Nacional das Quirimbas. Parque Nacional das Quirimbas, Pemba, Mozambique.

AWF (African Wildlife Foundation) (2005) Aerial Survey of the Marromeu Complex Reserve. Unpublished Report to Direção Nacional das Áreas de Conservação, Maputo, Mozambique.

Barbault, R. \& Sastrapradja, V. (1995) Generation, maintenance and loss of biodiversity. In Global Biodiversity Assessment (eds V.H. Heywood \& R.T. Watson), pp. 197-274. Cambridge University Press, Cambridge, UK.

Barbier, E.B., Burgess, J.C., Swanson, T.M. \& Pearse, D.W. (1992) Elephants, Economics and Ivory. Earthscan, London, UK.

Barnes, R.F.W., Craig, G.C., Dublin, H.T., Overton, G., Simons, W. \& Thouless, C.R. (1999) African Elephant Database 1998. Occasional Paper of the IUCN/Species Survival Commission no. 22. IUCN, Gland, Switzerland.

BARRETT, O.W. (1911) A região do Maputo: um território interesanteo elefante e o seu habitat. Relatórios e informações anexos. Boletim Oficial, 1, 120-122.

B ARRet O, P.R. (1745) Inquiry letter written to the Portuguese government concerning the establishment of trading forts along the Mozambican coast. Lourenço Marques, Mozambique. Available at Mozambique History Archive, Maputo, Mozambique.

BEE (Boletim Económico e Estatístico) (1925-1970) Agricultura e Comércio. Imprensa Nacional de Moçambique, Lourenço Marques, Mozambique.

BELL, R.H.V. (1987) Conservation with a human face: conflict and reconciliation in African land-use planning. In Conservation in Africa: People, Policies and Practice (eds D. Anderson \& R. Grove), pp. 79-101. Cambridge University Press, Cambridge, UK.

Bere, R. (1966) The African Elephant. Arthur Baker and Goleen Press, New York, USA

B LAIR, D.M. (1939) Human trypanosomiasis in southern Rhodesia, 1911-1938. Transactions of the Royal Society of Tropical Medicine and Hygiene, 32, 729-742.

Blanc, J.J., Barnes, R.F.W., Craig, G.C., Dublin, H.T., Thouless, C.R., Douglas-Hamilton, I. \& Hart, J.A. (2007) African Elephant Status Report 2007. An Update from the African Elephant Database. IUCN/Species Survival Commission African Elephant Specialist Group, Gland, Switzerland.

Blanc, J.J., Thouless, C.R., Hart, J.A., Dublin, H.T., DouglasHamilton, I., Craig, C.G. \& Barnes, R.F.W. (2003) African Elephant Status Report 2002. An Update from the African Elephant Database. IUCN/Species Survival Commission African Elephant Specialist Group, Gland, Switzerland.

Burlinson, J. \& Carter, J. (1976) Report of a Visit Made to Reserva Especial dos Elefantes. Universidade Eduardo Mondlane, Maputo, Mozambique.

Capela, J. \& Medeiros, E. (1987) O tráfico de escravos de Moçambique para as ilhas do Indico, 1720-1902. Colecção
Moçambique e a sua história. Universidade Eduardo Mondlane, Maputo, Mozambique.

CARNIE, T. (1999) A jumbo controversy: proposals to hunt bulls in Tembe Elephant Park draw sharp criticism. African Wildlife, 53, $20-21$.

Caughley, G. (1977) Analysis of Vertebrate Populations. John Wiley, New York, USA.

Chamberlain, G.A. (1923) African Hunting Among the Thongas. Harper \& Brothers, New York. USA.

Collins, C. (1978) Mozambique: dynamizing the people. A Journal of Opinion, 8, 12-16.

Correia, A.U., De Boer, F.W. \& Ntumi, C.P. (1996) Trabalho de Investigação junto à Reserva Especial de Maputo. In O papel da investigação na Zona Costeira (eds D. Dias, P. Scarlet, J. Hatton \& A. Macia), pp. 45-49. Universidade Eduardo Mondlane, Maputo, Mozambique.

Craig, G.C. \& Gibson, D.S. (2002) Aerial Survey of Wildlife in the Niassa Reserve and Hunting Concessions, Moçambique. Fauna \& Flora International, Cambridge, UK.

Craig, G.C. \& Gibson, D.S. (2004) Aerial Survey of Wildlife in the Niassa Reserve and Hunting Concessions, Moçambique. Fauna \& Flora International, Cambridge, UK.

Cumming, D. \& Jones, B. (2005) Elephants in Southern Africa: Management Issues and Options. WWF-Southern Africa Regional Programme Office Occasional Paper No. 11. WWF-SARPO, Harare, Zimbabwe.

Cumming, D.H.M., Mackie, C.S., Magane, S. \& Taylor, R.D. (1994) Aerial Census of Large Herbivores in the Gorongosa National Park and the Marromeu Area of the Zambezi Delta in Mozambique. Direcção Nacional de Florestas e Fauna Bravia, Maputo, Mozambique.

Dalquest, W.W. (1965) Mammals from the Save River, Mozambique, with descriptions of two new bats. Journal of Mammalogy, $46,254-264$.

Da Silva, L.A.R. (1969) Relatórios do Ministro e Secretário de estado dos Negócios da Marinha e do Ultramar apresentado às Cortes na sessão extraodinária de 1870, 2nd edição. Imprensa Nacional, Lisbon, Portugal.

Davies, C. (1999) Aerial Survey of Elephants and Other Large Animals in the Magoe District in North-west Tete Province, Mozambique: 1999. Multispecies Animal Production Systems Project, Project Paper 74. WWF-SARPO, Harare, Zimbabwe.

Deacon, J. (1984) Later Stone Age people and their descendants in southern Africa. In Southern Prehistory and Paleoenvironments (ed. R.G. Klein), pp. 221-328. A.A. Balkema, Boston, USA.

de Andrade e Silva, M.A. (1956) A tsé-tsé em Mozambique: a nossa acção contra a mosca e doenças que ela transmite. Imprensa Nacional de Mozambique, Lourenço Marques, Mozambique.

de Boer, F.W., Ntumi, C.P., Correia, A.U. \& Mafuca, J.M. (2000) Diet and distribution of elephant in the Maputo Elephant Reserve, Mozambique. African Journal of Ecology, 38, 188-201.

Del Gatto, F. (2003) Forest Law Enforcement in Mozambique: An Overview. DNFFB \& FAO, Maputo, Mozambique.

DiAs, J.A.T.S. (1971) Terão justificação os abates indiscriminados da caça como medida de luta contra a mosca tsé-tsé? Uma análise do caso de Moçambique. Revista de Ciências Veterinárias, 4, 87-100.

Dias, J.A.T.S. (1973) Alguns aspectos da caça clandestina em Moçambique e sugestões para se pôr cobro à destruição do nosso património cinegético. Revista de Ciências Veterinárias, $4,101-125$.

Dias, J.A.T.S. \& Rosinha, A.J. (1971) Proposta para a criação do Parque Nacional do Banhine. Revista de Ciências Veterinárias, 4, 175-197. 
DNAC (Direcção Nacional das Áreas de ConservaÇ̃̃o) (2006) Mapa das Áreas de Conservação de Moçambique. DNAC, Maputo, Mozambique.

DNFFB (Direcção Nacional de Florestas e Fauna Bravia) (1991) Elephant Conservation Plan for Mozambique. Ministério de Agricultura, Maputo, Mozambique.

DNFFB (Direcção Nacional de Florestas e Fauna Bravia) (1999) Elephant Management Strategy. Ministério de Agricultura, Maputo, Mozambique.

Douglas-Hamilton, I. (1984) Trends in key African elephant populations. Pachyderm, 4, 7-9.

Duarte, R.T. (1989) Arqueologia da idade do Ferro em Moçambique (1974-1988): retrospectiva do trabalho realizado. Universidade Eduardo Mondlane, Maputo, Mozambique.

Dutton, T.P. (1975) Mozambique's Maputo Elephant Reserve. African Wildlife, 29, 21-23.

Dutton, T.P. (1992) Wildlife victims of Mozambique's war. African Wildlife, 46, 67-69.

Dutton, T.P. (1994) A dream becomes a nightmare. African Wildlife, 48, 6-14.

Dutton, T.P. \& Dutton, E.A.R. (1973) Preliminary Ecological Reconnaissance of the Reserva Especial de Gile and Adjoining 'Regime de Vigilância' District of Zambezia. Imprensa Nacional de Moçambique, Lourenço Marques, Mozambique.

Dutton, T.P. \& Dutton, E.A.R. (1975) Reconhecimento preliminar das montanhas de Chimanimani e zonas adjacentes com vista à criação duma área de conservação. Anais dos Serviços de Veterinária de Moçambique, 20, 123-203.

Eastwood, E.B. \& Blundell, G. (1999) Rediscovering the rock art of the Limpopo-Shashi confluence area, Southern Africa. Southern African Field Archaeology, 8, 17-27.

Frade, F. (1950) Protecção à fauna de Moçambique: acerca dos ungulados do Maputo. Estudos de Zoología, 9, 187-193.

Gann, L.H. (1965) The History of Southern Rhodesia: Early Days to 1934. Chatto \& Windus, London, UK.

Gibson, D.S. (1998) Aerial Survey of Wildlife in and around Niassa Game Reserve, Mozambique. Sociedade para a Gestão e Desenvolvimento da Reserva do Niassa, Maputo, Mozambique.

Gibson, S.C.D. (2000) Aerial Survey of Wildlife in the Niassa Reserve and Hunting Concessions, Mozambique, October/November 2000. Sociedade para a Gestão e Desenvolvimento da Reserva do Niassa, Maputo, Mozambique.

HANKS, J. (2001) Conservation strategies for Africa's large mammals. Reproduction, Fertility and Development, 13, 459-468.

Harpending, H.C., Sherry, S.T., Rogers, A.L. \& Stoneking, M. (1993) The genetic structure of ancient human populations. Current Anthropology, 33, 483-496.

Hatton, J., Couto, M. \& Oglethorpe, J. (2001) Biodiversity and War: A Case Study of Mozambique. Biodiversity Support Program, Washington, DC, USA.

Hedges, D.W. (1978) Trade and politics in southern Mozambique and Zululand in the eighteenth and early nineteenth centuries. $\mathrm{PhD}$ thesis, University of London, London, UK.

HoAre, R.E. (2001) A Decision Support System (DSS) for Managing Human-Elephant Conflict Situations in Africa. IUCN African Elephant Specialist Group Report, Nairobi, Kenya.

Hofer, H., Hildebrandt, T.B., Goritz, F., East, M.L., Mpandui, D.G., Hahn, R. et al. (2004) Distribution and Movements of Elephants and Other Wildlife in the Selous-Niassa Wildlife Corridor, Tanzania. Tropical Ecology Support Programme, F-IV/12e, Eschborn, Germany.

Instituto Nacional de Meteorologia (2007) Http://www.inam. gov.mz [accessed 11 January 2007].
INE (Instituto Nacional de Estatística) (1980) Recenseamento Geral da População. Imprensa Nacional de Moçambique, Maputo, Mozambique.

INE (Instituto Nacional de Estatística) (1999) Moçambique em Números 1998. Instituto Nacional de Estatística, Maputo, Mozambique.

INE (Instituto Nacional de Estatí́stica) (2007) $3^{\circ}$ Recenseamento Geral da População e Habitação. Instituto Nacional de Estatística, Maputo, Mozambique.

Jordão, L.M. (1870) Memória sobre Lourenço Marques (Delagoa Bay). Imprensa Nacional de Moçambique, Lisbon, Portugal.

Keats, D. (1991) The wildlife utilization controversy: an African perspective. African Wildlife, 45, 71-75.

KLEIN, R.G. (1987) Reconstructing how early people exploited animals: problems and prospects. In The Evolution of Human Hunting (eds M.H. Nitecki \& D.V. Nitecki), pp. 11-45. Proceedings of the Field Museum of Natural History 9th Annual Spring Systematics Symposium on the Evolution of Human Hunting. Plenum Press, New York, USA.

Klingelhoeffer, E.W. (1987) Aspects of the ecology of the elephant Loxodonta africana (Blumenbach, 1797), and a management plan for the Tembe Elephant Reserve, Kwazulu. MSc thesis, University of Pretoria, Pretoria, South Africa.

Lee, P.C. \& Graham, M.D. (2006) African elephants Loxodonta africana and human-elephant interactions: implications for conservation. International Zoo Yearbook, 40, 9-19.

Leo-Smith, K., Balson, E.W. \& Abacar, A. (1997) Niassa Game Reserve: Management and Development Plan 1997-2006. Direcção Nacional de Florestas e Fauna Bravia/Investimentos Niassa Lda, Maputo, Mozambique.

LEwis, R.B. (1987) Were there elephant hunters at Torralba? In The Evolution of Human Hunting (eds M.H. Nitecki \& D.V. Nitecki), pp. 47-105. Proceedings of the Field Museum of Natural History 9th Annual Spring Systematics Symposium on the Evolution of Human Hunting. Plenum Press, New York, USA.

LieseganG, G. (1983) A first look at the import and export trade of Mozambique, 1800-1914. In Figuring African Trade (eds G. Liesegang, H. Pash \& A. Jones), pp. 452-523. Proceedings of the Symposium on the Quantification and Structure of the Import and Export and Long Distance Trade of Africa in the 19th Century (c. 1800-1913), St Augustin, USA.

Lorgen, C.C. (1999) Executive Summary of Report on the Experience of Villagization: Lessons from Ethiopia, Mozambique, and Tanzania. Unpublished Report. Oxfam, Oxford, UK.

Lyell, D. (1910) Hunting Trips in Northern Rhodesia: With Accounts of Sport and Travel in Nyasaland and Portuguese East Africa and also Notes on the Game Animals and their Distribution. Horace Cox, London, UK.

Lyell, D. (1924) The African Elephant and its Hunters. Heath Cranton, London, UK.

Mackie, C. (2001) Aerial Census of Elephants and Other Large Herbivores in the Magoe Region, Mozambique: 2001. WWF-SARPO, Harare, Zimbabwe.

MACкie, C. (2004) Aerial Census of Elephants and Other Large Herbivores in the Magoe Region, Mozambique: 2004. WWF-SARPO, Harare, Zimbabwe.

Mackie, C. \& Chafota, J. (1995) Aerial Survey of Large Mammals in Magoe District (North-west Tete Province) Moçambique. WWF-SARPO, Harare, Zimbabwe.

Maggs, T.M.O'C. (1984) The Iron Age south of the Zambezi. In Southern African Prehistory and Palaeoenvironments (ed. R.G. Klein), pp. 329-360. Balkema, Rotterdam, The Netherlands. 
Manghezi, A. (2003) Macassane: uma cooperative de mulheres velhas no sul de Moçambique. Documento 5. Arquivo Histórico de Moçambique, Maputo, Mozambique.

Martinho, J.P. (1968) A caça em Mozambique como factor de atracção turística e fonte importante de divisas. Boletim da Sociedade de Estudos de Mozambique, 37, 9-30.

Martins, A.R.O. \& Ntumi, C.P. (2002) Plant Diversity, Vegetation Ecological Status, Spatial and Temporal Movements of Elephants and Economic Value of Natural Resources in the National Reserve of Gilé, Zambézia Province-Mozambique. Unpublished Report to MOVIMONDO/UE, Maputo, Mozambique.

Maugham, R.C.F. (1914) The Elephant. John Murray, London, UK.

Maximiano, N.L.B., Arndt, C. \& Simler, K.R. (2005) Qual foi a dinâmica dos determinantes da pobreza em Moçambique? Ministério de Planificação e Desenvolvimento, Maputo, Mozambique.

MICOA (MinistéRIO DA CoORdEnAÇão DA ACÇÃo Ambiental) (1997) Strategy and Areas for Action for the Conservation of Biological Diversity in Mozambique. MICOA, Maputo, Mozambique.

Milliken, T. (2002) Maputo's ivory markets, Mozambique. Traffic Bulletin, 19, 56-57.

MINAG (Ministério DA Agricultura) (2006) Estratégia Nacional de Mitigação do Conflito Homem-Animal. MINAG, Maputo, Mozambique.

Morley, R.C. \& van Aarde, R.J. (2007) Estimating abundance for a savannah elephant population using mark-resight methods: a case study for the Tembe Elephant Park, South Africa. Journal of Zoology, London, 271, 418-427.

NTUMi, C.P. (2002) Space and habitat use by elephants (Loxodonta africana) in the Maputo Elephant Reserve, Mozambique. MSc thesis, University of Pretoria, Pretoria, South Africa.

Ostrosky, E.W. \& Matтhews, W.S. (1995) The Transfrontier Conservation Initiatives in Southern Maputo Province, Mozambique: Comments on Feasibility of the Futi Corridor. Direcção Nacional de Florestas e Fauna Bravia, Maputo, Mozambique.

OWEn-SMIth, R.N. (1999) The interaction of humans, megaherbivores, and habitats in the Late Pleistocene extinction event. In Extinctions in Near Time: Causes, Contexts and Consequences (eds R.D.E. Macphee \& H.D. Seus), pp. 57-69. Klewer Academic/ Plenum Publishers, New York, USA.

PARDAL, J.C. (1996) Cambaco I, 2nd edition. Editora MirebéricaLiber Editores, Lisbon, Portugal.

Pereira, C.R. (2001) Charcoal Potential in Southern Africa. Final Report for Mozambique. International Cooperation with Developing Countries (1998-2001). Contract Number ERBIC18CT980278. CHAPOSA, Maputo, Mozambique.

RM (República de Moçambique) (2006) Plano de Acção para a Redução de Pobreza Absoluta 2006-2009. Ministério do Plano e Finanças, Maputo, Mozambique.

Rodrigues, P.V. (1917) Relatório duma caçada aos elefantes na circunscrição do Maputo. Lourenço Marques, Mozambique.

RP (Pepública Portuguesa) (1952) Caça em Mozambique: África Oriental Portuguesa. Litografia Nacional, Porto, Portugal.

S AKet, M. (1994) Forest Mapping at 1:250,000. Vegetation Classification System. Ministério de Agricultura/DNFFB, Maputo, Mozambique.

Sanderson, I.T. (1962) The Dynasty of Abu: A History and Natural History of the Elephants and their Relatives, Past and Present, 2nd edition. Curtis Publishing Company, New York, USA.

Selous, F.C. (1984) Travel and Adventure in South-east Africa. Time-Life, Amsterdam, The Netherlands.
Shepperson, G. (1965) David Livingstone and the Rovuma. Edinburgh University Press, Edinburgh, UK.

Sheriff, A. (1983) Slaves, Spices and Ivory in Zanzibar. British Library Cataloguing in Publication Data, London, UK.

Sherry, S., Rogers, A.R., Harpending, H., Soodyall, H., Jenkins, T. \& Stoneking, M. (1994) Mismatch distributions of mtDNA reveal recent human population expansions. Human Biology, 66, 761-775.

Silva, T.C. (1980) First indications of Early Iron Age in southern Mozambique: Matola IV 1/68. In Proceedings of the 8th Pan African Congress of Prehistory and Quaternary Studies, Nairobi, 1977 (eds R.E. Leakey \& B.A. Ogot), pp. 349-350. International Louis Leakey Memorial Institute for African Prehistory, Nairobi, Kenya.

Sinclair, P.J.J. (1991) Archaeology in Eastern Africa: an overview of current chronological issues. The Journal of African History, 32, 179-219.

SinClair, P.S. (1987) Um reconhecimento Arqueológico do Norte de Moçambique, Província de Cabo Delgado. Trabalhos de Arqueologia e Antropologia, 3, 20-44.

Sitoe, S., Guissamulo, A. \& N tumi, C.P. (2003) Distribuição e uso de habitat por elefantes na Reserva Florestal de Moribane, TFCA Chimanimani. Unpublished Report. Universidade Eduardo Mondlane, Maputo, Mozambique.

Smithers, R.H.N. \& Tello, J.P.L. (1976) Checklist and Atlas of the Mammals of Mozambique. Museum Memoir number 8. National Museum and Monuments, Salisbury, Rhodesia.

Sokal, R.R. \& Rohlf, F.J. (1995) Biometry, 3rd edition. W.H. Freeman and Company, New York, USA.

Spinage, C. (1994) Elephants. T \& AD Poyser, London, UK.

SRN (Sociedade para a Gestão e Desenvolvimento da Reserva do Niassa) (2006) Regulamento de Caça ao elefante na Reserva do Niassa. Unpublished Report. Maputo, Mozambique.

Stalmans, M. (2004) Banhine Wildlife Census. Unpublished Technical Report commissioned by the African Wildlife Foundation. Development Alternatives, Nelspruit, South Africa.

St almans, M. (2007) Parque Nacional de Banhine Wildlife Survey. Unpublished Technical Report commissioned by ACTF-MITUR. International Conservation Services, White River, South Africa.

St almans, M. (2007) Parque Nacional de Zinave Wildlife Survey. Unpublished Technical Report commissioned by ACTF-MITUR. International Conservation Services, White River, South Africa.

STOCK, J.T. \& PFEIFFER, S.K. (2001) Linking structural variability in long bone diaphyses to habitual behaviours: foragers from the Southern African Later Stone Age and the Andaman Islands. American Journal of Physical Anthropology, 115, 337-348.

TAYlor, R.D. (1981) An Ecological Survey of the Mueda Plateau and the Rovuma-Lugenda Confluence Northern Moçambique. Unpublished Report to Empresa Moçambicana de Fauna, Maputo, Mozambique.

Tello, J.L.P.L. (1973) Reconhecimento ecológico da Reserva dos elefantes do Maputo. Veterinária de Moçambique, 6, 133-186.

Tello, J.L.P.L. (1977) Situação em Moçambique de algumas espécies mamalógicas de grande porte, consideradas em vias de extinção. Boletim da DINAP de Mozambique, 1, 55-132.

Tello, J.L.P.L. (1986) Wildlife in Mozambique: Current Status and Problems. Report to WWF, Maputo, Mozambique.

Tinley, K.L. \& Dutton, T.P. (1973) Aerial Survey at the Maputo Elephant Reserve. Unpublished Report. Lourenço Marques, Mozambique.

Tinley, K.L., Rosinha, A.J., Tello, J.L.P.L. \& Dutton, T.P. (1976) Wildlife and wild places in Mozambique. Oryx, 13, 344-350. VAn AARDE, R.J. \& JACkson, T.P. (2007) Megaparks for metapopulations: addressing the causes of locally high elephant numbers in southern Africa. Biological Conservation, 134, 289-297. 
van Aarde, R.J., Jackson, T.P. \& Ferreira, S.M. (2006) Conservation science and elephant management in southern Africa. South African Journal of Science, 102, 385-388.

Whyte, I.J., van Aarde, R.J. \& Stuart, P. (2003) Kruger's elephant population: its size and consequences for ecosystem heterogeneity. In The Kruger Experience: Ecology and Management of Savannah Heterogeneity (eds J.J. du Toit, K.H. Rodgers \& H.C. Biggs), pp. 332-348. Island Press, Washington, DC, USA.

Wild, H. \& BArbosa, L.A. (1967) Vegetation Map of the Flora Zambesiaca area. In Flora Zamesiaca. Mozambique, Malawi, Zambia, Rhodesia, Botswana (eds H. Wild \& A. Frenandez), pp. 1-71. A.M.O. Collins, Salisbury, Rhodesia.

Woodhouse, H.C. (1996) Elephants in rock art. The Rhino and Elephant Journal, 10, 24-27.

WWF/IUCN (1980) Advisory Mission to the Government of the Popular Republic of Mozambique. Report to the Government of the Popular Republic of Mozambique. WWF/IUCN, Gland, Switzerland.

\section{Biographical sketches}

Cornelio P. Ntumi is studying landscape approaches to elephant conservation in Mozambique. He has an interest in conservation ecology, with a particular emphasis on spatial and habitat use by species and the factors influencing this. SAM M. FERREIRA's research focuses on conservation biology and, in particular, temporal dynamics and the factors influencing these. RUDI J. VAN AARDE's research focuses on the restoration of populations and communities as a contribution to conservation. His research on elephants covers populations in Botswana, Malawi, Mozambique, Namibia, South Africa and Zambia. 